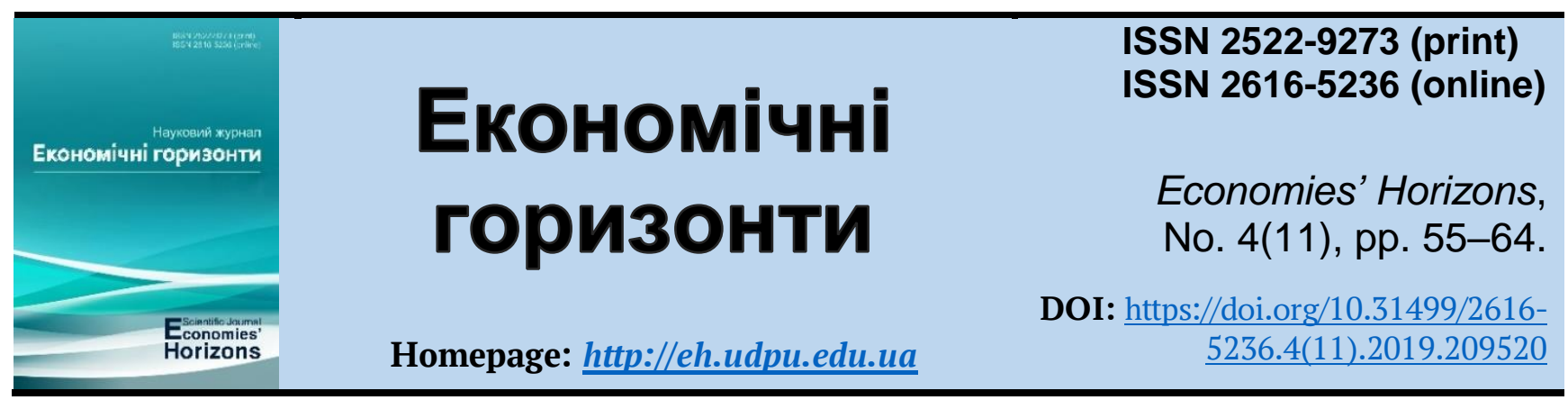

UDC 338.439: 33:005.57:004.77

\title{
Investment component in promoting the development of the digital economy and society
}

\author{
Oleksandr F. Senkevich ${ }^{1}$
}

Received: 15 October 2019

Accepted: 18 November 2019
Senkevich, O. F. (2019), "Investment component in promoting the development of the digital economy and society", Economies' Horizons, no. 4(11), pp. 55-64, doi: https://doi.org/10.31499/2616-5236.4(11).2019.209520.

Abstract. The purpose of the article is to substantiate the investment component in promoting the development of the digital economy and society. Methodology. General scientific methods are used in the research, in particular system economic analysis - to substantiate the strategic dominants of the digital transformation of the economy; statistical analysis - to study the current state and trends in foreign direct investment in digitalization; methods of positive and normative analysis - to develop recommendations for improving the investment component in promoting the development of the digital economy and society. Results. The analysis of the capital investment dynamics by section of information and telecommunications for 2010-2018 shows an increase in the share of telecommunications in its total capital investment by 0.38 percentage points. This increase was due to a slight increase in telecommunications investment in 2018 and an overall increase in capital investment. In general, capital investment increased 3.2 times in eight years, and investment in information and telecommunications - 3.5 times. It is proved that significant innovative changes in telecommunications, the transition to $3 \mathrm{G}$ and $4 \mathrm{G}$ in 2015 and 2018 increased the amount of investment in these periods by 14,799.9 million UAH and $11,489.7$ million UAH, respectively. According to the growth rate, it is necessary to note the receipts in the area of computer programming and the provision of other information services, which increased 11 times (telecommunications - 3.4 times, publishing, radio, television - 2.5 times). It is noted that foreign direct investment in the economic activity of information and telecommunications has a positive trend to increase from 1,734.9 million USD in 2010 to 2,201.1 million USD in 2018. These investments also characterize a favorable investment climate for foreign investors when investing in digitalization. It is proved that today in Ukraine the most attention is paid to the creation of high-tech and engineering clusters. In addition, the development of intersectoral alliances, R\&D centers, laboratories, incubators, accelerators, venture funds and innovation teams is promising. The strategic dominants of the economy digital transformation are determined. Practical meaning. The main priority projects for investing in transformation infrastructure in 2020-2030 are presented. Prospects for further research. It is substantiated that the model of financing through venture capital, business angels, grants, business incubators, accelerators, crowdfunding platforms, innovation teams is expedient for innovative projects. It can be through raising funds in the stock market, through IPOs, SPOs, ISOs, direct investment funds, mutual investment institutions, state and non-state pension funds.

\footnotetext{
${ }^{1}$ Admiral Makarov National University of Shipbuilding; Applicant at the Department of Management; ORCID ID: https://orcid.org/0000-0002-0226-9463; e-mail: management@nuos.edu.ua; Scientific Adviser I. O. Irtyshcheva, Doct. Ec. Sc., Professor.
} 
Keywords: investment component, digitalization, digital economy, society.

JEL Classification: L 86, R 10, R 23.

Number of references: 16; number of tables: 1; number of figures: 2; number of formulas: $\mathbf{0 .}$

\section{Інвестиційна складова у сприянні розвитку цифрової економіки та суспільства}

\section{Олександр Федорович Сєнкевич ${ }^{1}$}

Стаття надійшла: 15.10 .2019 Стаття прийнята: 18.11.2019
Senkevich O. F. Investment component in promoting the development of the digital economy and society. Економічні горизонти. 2019. № 4(11). C. 55-64. DOI: 10.31499/2616-5236.4(11).2019.209520.

Анотація. Метою статті є обгрунтування інвестиційної складової у сприянні розвитку цифрової економіки та суспільства. Методологія. У досліджені застосовані загальнонаукові методи, зокрема системного економічного аналізу - для обгрунтування стратегічних домінант цифрової трансформації економіки; статистичного аналізу - для дослідження сучасного стану та тенденцій розвитку прямих іноземних інвестицій в цифровізацію; методи позитивного і нормативного аналізу - для вироблення рекомендацій з удосконалення інвестиційної складової у сприянні розвитку цифрової економіки та суспільства. Результати. Аналіз динаміки капітального інвестування за секцією діяльності інформація та телекомунікації за 2010-2018 роки свідчить про зростання частки телекомунікацій в його загальному обсязі капітальних інвестицій на $0,38 \%$. Таке підвищення відбулося внаслідок незначного збільшення інвестування телекомунікацій у 2018 році і загальним зростання суми капітальних інвестицій. В цілому, якщо за вісім років капітальні інвестиції збільшилися в 3,2 рази, то інвестиції за видом економічної діяльності інформація та телекомунікації в 3,5 разів. Доведено, що суттєві інноваційні зміни в телекомунікаціях (електрозв’язку), перехід на 3G й 4G у 2015 та 2018 роках збільшували обсяг капіталовкладень у ці періоди на 14 799,9 млн грн й 11 489,7 млн грн відповідно. Відзначено, що за темпами зростання необхідно відмітити надходження за напрямом комп'ютерне програмування та надання інших інформаційних послуг, які збільшилися в 11 раз, при цьому телекомунікації - 3,4 рази та видавничу діяльність, радіомовлення, телебачення - 2,5 рази. Зазначено, що прямі іноземні інвестиції внесені у вид економічної діяльності інформація та телекомунікація мають позитивну тенденцією до збільшення $з 1$ 734,9 млн. дол. США у 2010 році до 2 201,1 млн. дол. США у 2018 році та характеризують спритний інвестиційний клімат для іноземних інвесторів при вкладі коштів в цифровізацію. Доведено, що найбільшу увагу сьогодні в Україні приділяють створенню хай-тек, інжиніринговим кластерам, окрім того визначають перспективним розвиток міжгалузевих альянсів, R\&D-центрів, лабораторій, інкубаторів, акселераторів, венчурних фондів, інноваційним командам. Визначено стратегічні домінанти цифрової трансформації економіки. Наведено основні пріоритетні проєкти для інвестування в трансформаційну інфраструктуру у 20202030 роках. Практичне значення. Наведено основні пріоритетні проєкти для інвестування в трансформаційну інфраструктуру у 2020-2030 роках. Перспективи подальших досліджень. Обгрунтовано, що перспективним для подальших досліджень розвитку цифрової економіки модель фінансування через венчурний капітал, бізнес-ангелів, гранти, бізнес-інкубатори, акселератори, краудфандингові платформи, інноваційні команди для інфраструктурних через залучення коштів на фондовому ринку, через IPO, SPO, ICO, фонди прямих інвестицій, інститути спільного інвестування, державні і недержавні пенсійні фонди.

$\begin{array}{llll}1 & \text { Національного університету кораблебудування імені адмірала Макарова; здобувач кафедри } \\ \text { менеджменту; } & \text { ідентифікатор ORCID: } & \text { https://orcid.org/0000-0002-0226-9463; } & \text { e-mail: }\end{array}$

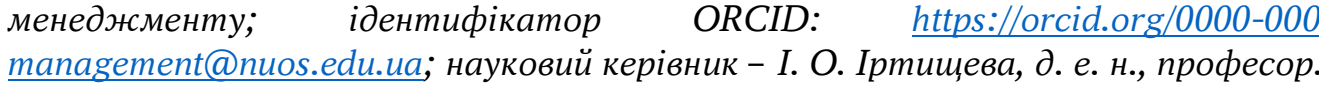


Ключові слова: інвестиційна складова, цифровізація, цифрова економіка, суспільство

Кількість джерел: 16; кількість таблиць: 1; кількість рисунків: 2; кількість формул: 0.

\section{Introduction.}

Modern transformation processes are a prerequisite for the development of the concept of "Industry 4.0", where cyber-physical systems are the main, defining technological component. "Industry 4.0 " includes the digitalization of all socially important areas of the economy, such as: public safety and security, health, education, public administration, ecology, "smart city", e-commerce, e-customs, social sphere. It is clear that digital transformation is not possible without significant investment, and therefore the study of the investment component is a very important element in promoting the development of the digital economy and society.

Problem formulation. It is necessary to agree with the statement of F. Fishchuk and A. Biriukov that “...Ukraine's economy today is losing in the field of digital transformations. Out of focus are such important components of building a digital economy as:

- digitization by sectors and branches of the economy, "Industry 4.0";

- digitalization of life spheres, including medicine, education, security, ecology, transport, etc.;

- digital infrastructure, overcoming the digital inequality;

- digital society, digital rights, digital competencies, etc.;

- digitization of physical infrastructure" (Fishchuk and Biriukov, 2019).

However, it should be noted that in recent years the role of digitalization in the socio-economic life of the population has significantly increased.

\section{Literature review.}

Domestic and foreign scientists have paid considerable attention to the formation of the investment component of the digital economy, taking place in society under the influence of digitalization, in particular: L. Zakharchenko (2013), I. Irtyshcheva and
I. Kramarenko (2014), Ye. Romanenko (2016), M. Aleksinska, A. Bastrakova and N. Kharchenko (2018), A. Simakhova (2018), I. Irtyshcheva et al. (2019), K. Shtepenko and O. Zaburaeva (2019), M. Melnyk (2019), I. Irtyshcheva, O. Vyshnevska and O. Kaliuzhna (2019), V. Zagariy, T. Kovalchuk and V. Sinilnyk (2019), I. Irtyshcheva, M. Ponomarova and I. Dolzhykova (2019), F. Fishchuk and A. Biriukov (2019) and others. But at the same time, a significant number of problems regarding the vision of the investment component in promoting the development of the digital economy and society, the directions of its development remain insufficiently disclosed. The current scientific views of scientists on the investment component and the impact on the development of the digital economy and society are not fully reflected in the available scientific achievements.

\section{Methodology.}

The theoretical and methodological basis of the study is the scientific works of scientists in the field of digital economy. To achieve the purpose of the Paper, the following research methods were used: system economic analysis - to substantiate the strategic dominants of the digital transformation of the economy; statistical analysis - to study the current state and trends in foreign direct investment in digitalization; methods of positive and normative analysis - to develop recommendations for improving the investment component in promoting the development of the digital economy and society.

\section{Research objectives.}

The purpose of the article is to substantiate the investment component in promoting the development of the digital economy and society.

\section{Results and discussions.}

Noting the positive changes in the direction of increasing revenues from information and telecommunications as a type of economic 
activity, there is a need to study the level of capital investment in the field of digitalization. The data of the International Telecommunication Union on the level and dynamics of the ICT development index, according to which Ukraine ranked 79th in 2017, are confirmed by the lag in the development and spread of ICT in recent years, as Ukraine has worsened its position by 10 points since 2010 . It should be noted that according to the ICT development index 2017, our country is the only one of the CIS countries that has worsened rather than improved its position (ICT development index, 2017). Therefore, there is an urgent need to increase the production capacity of entities operating in the field of ICT. However, the amount of investment received is insufficient.

The analysis of the dynamics of capital investment by information and telecommunications section for 2010-2018 shows an increase in the share of telecommunications in its total capital investment by 0.38 percentage points. This increase was due to a slight increase in telecommunications investment in 2018 and an overall increase in capital investment. In general, capital investment increased 3.2 times in eight years, and investment in information and telecommunications - 3.5 times. Quite interesting is their rapid growth in 2015 due to significant investment in telecommunications.

Over the past three years, investment in computer programming and other information services has increased by $99.9 \%$ and in publishing, broadcasting and television - by $68 \%$. At the same time, it should be noted a significant reduction in investment in 2016 and 2017 in the telecommunications sector by $46 \%$ and $35 \%$, respectively. In 2015, a significant amount of investment in the telecommunications sector was provided by an increase in investment by $344.9 \%$ compared to 2014 . The corresponding increase in capital investment in 2015 is due to significant investments by mobile providers of almost UAH 16 billion for the purchase of a $3 \mathrm{G}$ license and for the development of telecommunications networks.
However, according to the growth rate, it is necessary to note the receipts in the area of computer programming and provision of other information services, which increased 11 times, with telecommunications - 3.4 times and publishing, broadcasting, television -2.5 times.

Even with a significant increase in investment in computer programming and other information services, Ye. Romanenko determines that "Ukraine lags behind the level of many European countries. The reasons are: almost complete lack of state funding for research, insufficient assessment of international and European experience, lack of necessary regulatory documents, the presence of contradictions in terminology and a number of current regulations that lead to some spontaneity and distortion in the development of the information society" (Romanenko, 2016).

It should be noted that significant innovative changes in telecommunications, the transition to $3 \mathrm{G}$ and $4 \mathrm{G}$ in 2015 and 2018 increased the amount of investment in these periods by $14,799.9$ million UAH and $11,489.7$ million UAH, respectively.

L. Zakharchenko notes that "despite the positive dynamics of investment development, the potential of the ICT sector of Ukraine remains untapped, which significantly inhibits socio-economic development and reduces the competitiveness of the state among other economies of the world. Therefore, the priority task of the ICT development in Ukraine is to create appropriate conditions for attracting a significant amount of investment both from enterprises of the ICT industry and from consumers of the ICT products and services" (Zakharchenko, 2013).

The analysis of foreign direct investment in the Ukrainian economy for 2010-2018 showed a significant reduction from 45,370 million US dollars to 32,905 million US dollars, respectively (Table 1). At the same time, the devaluation of the national currency may show the opposite values of the foreign investment growth in the economy. 
Table 1. Foreign direct investment structure by types of economic activity

\begin{tabular}{|c|c|c|c|c|c|c|c|c|}
\hline \multirow{2}{*}{$\begin{array}{c}\text { Type of economic } \\
\text { activity }\end{array}$} & \multicolumn{2}{|l|}{\begin{tabular}{|r|}
2010 \\
\end{tabular}} & \multicolumn{2}{|l|}{2013} & \multicolumn{2}{|l|}{2015} & \multicolumn{2}{|l|}{2018} \\
\hline & million USD & $\%$ & million USD & $\%$ & million USD & $\%$ & million USD & $\%$ \\
\hline $\begin{array}{l}\text { agriculture, for- } \\
\text { estry and fisheries }\end{array}$ & 719.5 & 1.59 & 776.9 & 1.45 & 502.2 & 1.56 & 451.9 & 1.37 \\
\hline industry & $18,693.80$ & 41.20 & $17,681.40$ & 32.92 & $9,893.60$ & 30.80 & $10,823.40$ & 32.89 \\
\hline construction & $1,111.20$ & 2.45 & $1,580.00$ & 2.94 & $1,104.10$ & 3.44 & 983.5 & 2.99 \\
\hline $\begin{array}{l}\text { wholesale and re- } \\
\text { tail trade; repair of } \\
\text { motor vehicles and } \\
\text { motorcycles }\end{array}$ & $4,681.10$ & 10.32 & $6,807.80$ & 12.68 & $5,247.40$ & 16.34 & $5,480.20$ & 16.65 \\
\hline $\begin{array}{l}\text { transport, ware- } \\
\text { housing, postal } \\
\text { and courier activi- } \\
\text { ties }\end{array}$ & $1,027.10$ & 2.26 & $1,535.30$ & 2.86 & $1,088.00$ & 3.39 & $1,043.00$ & 3.17 \\
\hline $\begin{array}{l}\text { temporary accom- } \\
\text { modation and ca- } \\
\text { tering }\end{array}$ & 353 & 0.78 & 446.5 & 0.83 & 332.6 & 1.04 & 355.5 & 1.08 \\
\hline $\begin{array}{l}\text { information and } \\
\text { telecommunica- } \\
\text { tions }\end{array}$ & $1,734.90$ & 3.82 & $1,894.70$ & 3.53 & $2,089.40$ & 6.50 & $2,201.10$ & 6.69 \\
\hline $\begin{array}{l}\text { financial and in- } \\
\text { surance activities }\end{array}$ & $11,498.30$ & 25.34 & $12,261.40$ & 22.83 & $4,350.10$ & 13.54 & $3,641.10$ & 11.07 \\
\hline $\begin{array}{l}\text { real estate transac- } \\
\text { tions }\end{array}$ & $3,045.60$ & 6.71 & $4,768.30$ & 8.88 & $3,882.10$ & 12.09 & $4,258.20$ & 12.94 \\
\hline $\begin{array}{l}\text { professional, sci- } \\
\text { entific and tech- } \\
\text { nical activities }\end{array}$ & $1,182.00$ & 0.03 & 0.00 & 0.00 & $2,222.60$ & 6.92 & $2,096.90$ & 6.37 \\
\hline $\begin{array}{l}\text { activities in the } \\
\text { field of adminis- } \\
\text { trative and support } \\
\text { services }\end{array}$ & $1,110.80$ & 2.45 & $1,686.90$ & 3.14 & $1,222.70$ & 3.81 & $1,377.40$ & 4.19 \\
\hline education & 0.1 & 0.00 & 0.1 & 0.00 & - & - & - & - \\
\hline $\begin{array}{l}\text { health care and so- } \\
\text { cial assistance }\end{array}$ & 7.6 & 0.02 & 12 & 0.02 & 16 & 0.05 & 22.2 & 0.07 \\
\hline $\begin{array}{l}\text { art, sports, enter- } \\
\text { tainment and rec- } \\
\text { reation }\end{array}$ & 50.7 & 0.11 & 59.9 & 0.11 & 44 & 0.14 & 43.5 & 0.13 \\
\hline $\begin{array}{l}\text { other types of ser- } \\
\text { vices }\end{array}$ & 130.9 & 0.29 & 157 & 0.29 & 112.5 & 0.35 & 99.8 & 0.30 \\
\hline Total & 45,370 & 100.00 & 53,704 & 100.00 & 32,122 & 100.00 & 32,905 & 100.00 \\
\hline
\end{tabular}

Source: compiled and calculated according to the State Statistics Service of Ukraine (2019).

Undoubtedly, for the entire period of the study, the leader among attracting investment is industry - almost $10,823.4$ million USD or $32.89 \%$ of the total share of foreign direct investment. The leading types of economic activity, in terms of direct investment, in 2018 are: wholesale and retail trade - 5,480.2 million USD or $16.65 \%$ of the total share of foreign direct investment; repair of motor vehicles and motorcycles $-5,480.2$ million USD or
16.65\%; real estate transactions - 4,258.2 million USD or $12.94 \%$; financial and insurance activities - 3,641.1 million USD or $11.07 \%$; information and telecommunications - 2,201.1 million USD or $6.69 \%$; professional, scientific and technical activities - 2,096.9 million USD or $6.37 \%$, respectively.

Foreign direct investment in information and telecommunications is progressing positively from USD $1,734.9$ million in 2010 to 
USD 2,201.1 million in 2018.

The process of attracting foreign direct investment to our country is accompanied by the problems. K. Shtepenko and O. Zaburaeva have substantiated in the study that "the problem of property rights protection is one of the most important. It is the investors' uncertainty about the possibility of preserving their property that significantly inhibits the intention to invest capital and the desire to conduct business. The low level of economic activity is also affected by military action in the east and the associated risks of aggravation, haphazard changes in public investment policy, widespread corruption, lack of confidence in the judiciary, unpredictable exchange rates and an unstable financial system" (Shtepenko and Zaburaeva, 2019).

According to M. Melnyk, today especially large cities generate not only trends of social development, but also new ideas, where new concepts of sustainable development are implemented ("smart cities", "creative cities", "green cities", "learning cities", etc.). They test the latest elements of local government (egovernment, participatory government, etc.). Therefore, the competitiveness of regions and the country as a whole depends on the vector and level of urban development, in particular, promising and creative economic activities based on self-identification and key competitive advantages of their development (Melnyk, 2019).

Also, Ukraine is a leader among European countries in the use of digital platforms, in particular in financing and performing certain tasks. It is difficult to estimate the total investment in digital platforms, but it is possible to consider the main functional features.

Among the largest digital platforms originating in Ukraine are: Freelancehunt.com (programming, design / art, audio / video, optimization (SEO / SMM), architecture and engineering, mobile applications, administration, outsourcing and consulting, translations, work with texts), Kabanchik.ua (typing, data entry, copyright, content filling sites, creating presentations, developing web and mobile applications, design, online advertising, web design, etc.), Freelance.ua (3D graphics, animation, art, architecture / interior, audio / video, outsourcing and consulting, design, engineering, management, mobile applications, training and consulting, advertising (SEO, SMM), translation, printing, programming, web development sites, advertising and marketing, networks and information systems, texts, flash, photography). However, Ukrainians use other platforms for work: Upwork.com (USA), Freelance.ru, Fl.ru, Weblancer.net (Russia), Freelancer.com (Australia) (Aleksinska, Bastrakova and Kharchenko, 2018).

It should be noted the importance of the development of crowdfunding and crowdfunding platforms in Ukraine in the process of investment transformation. After all, crowdfunding platforms are intermediaries in the successful search for investors.

Among the main prerequisites for creating a successful digital transformation of the economy is the development of clusters. The most concentrated implementation of investment interaction is manifested in the framework of IT clusters, as one of the main elements of the Ukrainian IT ecosystem.

The formation of IT clusters takes place through associations in the main regional centers of the IT sector of Ukraine, IT companies together with local authorities, specialized educational institutions and service structures in the field of information and communication technologies (ICT). The main goal of the association is the joint implementation of projects that will enhance the development of the IT sector and high technology in the national and international levels, the implementation of various social and infrastructure projects, and the implementation of systemic changes in the business environment of their cities and regions. Leading IT outsourcing companies have become the core of IT clusters in large cities of Ukraine, as the Ukrainian IT sector is mainly an outsourcing development industry (Kramarenko et al., 2019).

Today, the greatest attention in Ukraine is paid to the creation of high-tech, engineering 
clusters. In addition, the development of intersectoral alliances, R\&D centers, laboratories, incubators, accelerators, venture funds, and innovation teams is promising.

It is necessary to identify important investment project areas of IT clusters in the context of sustainable development goals:

- development and modernization of education within their cities and regions;

- activation of the professional network and assistance in establishing contacts between IT experts;

- promoting the development of a city or region by increasing their level of competitiveness across the country;

- formation of a positive image;

- social infrastructure improvement;

- dialogue with local authorities on improving and developing IT, as well as implementing systemic changes in the business environment of the city.

It is important to develop effective directions and priorities for the development of digitalization both in Ukraine in general and at the local level. Directions and priorities for the development of the digital economy should cover all socially important areas: medicine, education, security, ecology, economics (Figure 1).

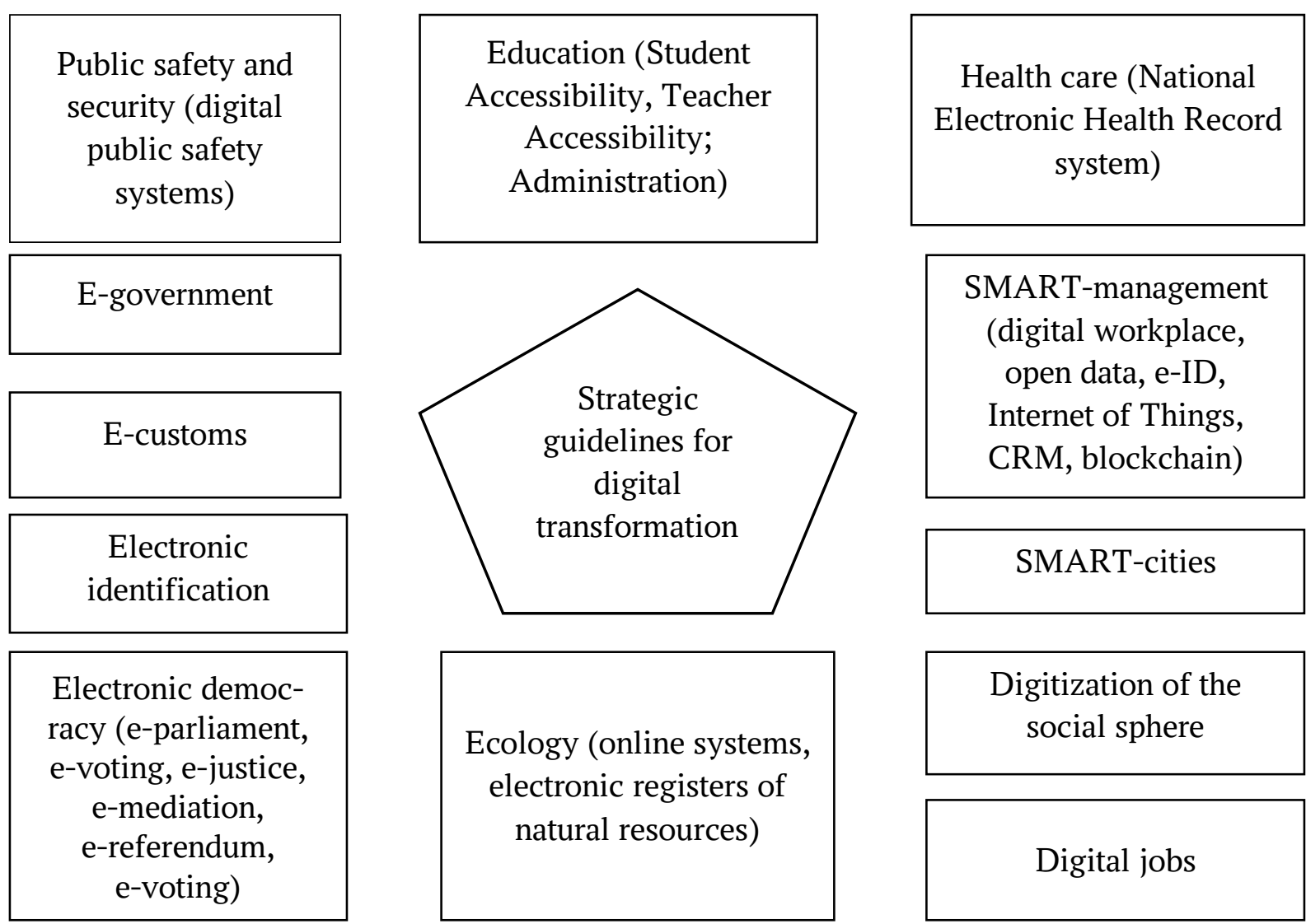

Fig. 1. Strategic dominants of digital transformation of the economy Source: grouped by author.

It should be noted that today digitalization has already absorbed education, medicine, management, economics. Thus, the recently adopted medical reform calls for the development of telemedicine in regions inaccessible for prompt access (mostly in rural areas). In a world where access to mobile communications is ahead of access to electricity and water, telemedicine is an initiative that can and should build a bridge between a patient and a doctor. Filling out declarations for the maintenance and implementation of the helsi.me site has greatly simplified the lives of ordinary citizens. The most significant changes have taken place in education. The Prometheus project is a clear example of how effective governance can build a strong education system in Ukraine. Digitization of the educational 
process is rapid. Today there are online courses, online conferences, online testing, webinars. This format has long been an integral part of citizens (Zagariy, Kovalchuk and Sinilnyk, 2019).

In fact, it is necessary to agree with A. Simakhova that "the main advantages of science and digital economy for sustainable development and social welfare are:

- increasing competition and quality of products and services;

- reduction of production costs and product prices; vices;

- expanding the range of goods and ser-

- increasing the availability of goods and services for ordinary citizens through the use of the Internet;

- development of technologies in the medical field that will promote the treatment of deadly diseases;

- emergence of new professions;

- higher mobility and flexibility of the education system (higher, vocational and technical education);

- use of scientific developments to improve the environmental situation in the country;

- increasing life expectancy;

- improving the life quality of the population" (Simakhova, 2018).

Among the main advantages of digitalization is a significant future promising investment that will bring a total economic effect. However, the main problem hindering the development of digitalization in Ukraine is the imperfect digital infrastructure. Among the defining issues that worsen the situation of the digital infrastructure are: low level of coverage in the country, lack of separate digital infrastructures, unequal access of citizens to information technologies and new opportunities. Thus, Ukrainian society faces the global challenge of restructuring the digital infrastructure. The highest priority projects for investment in transformation infrastructure in 2020-2030 are shown in Figure 2.

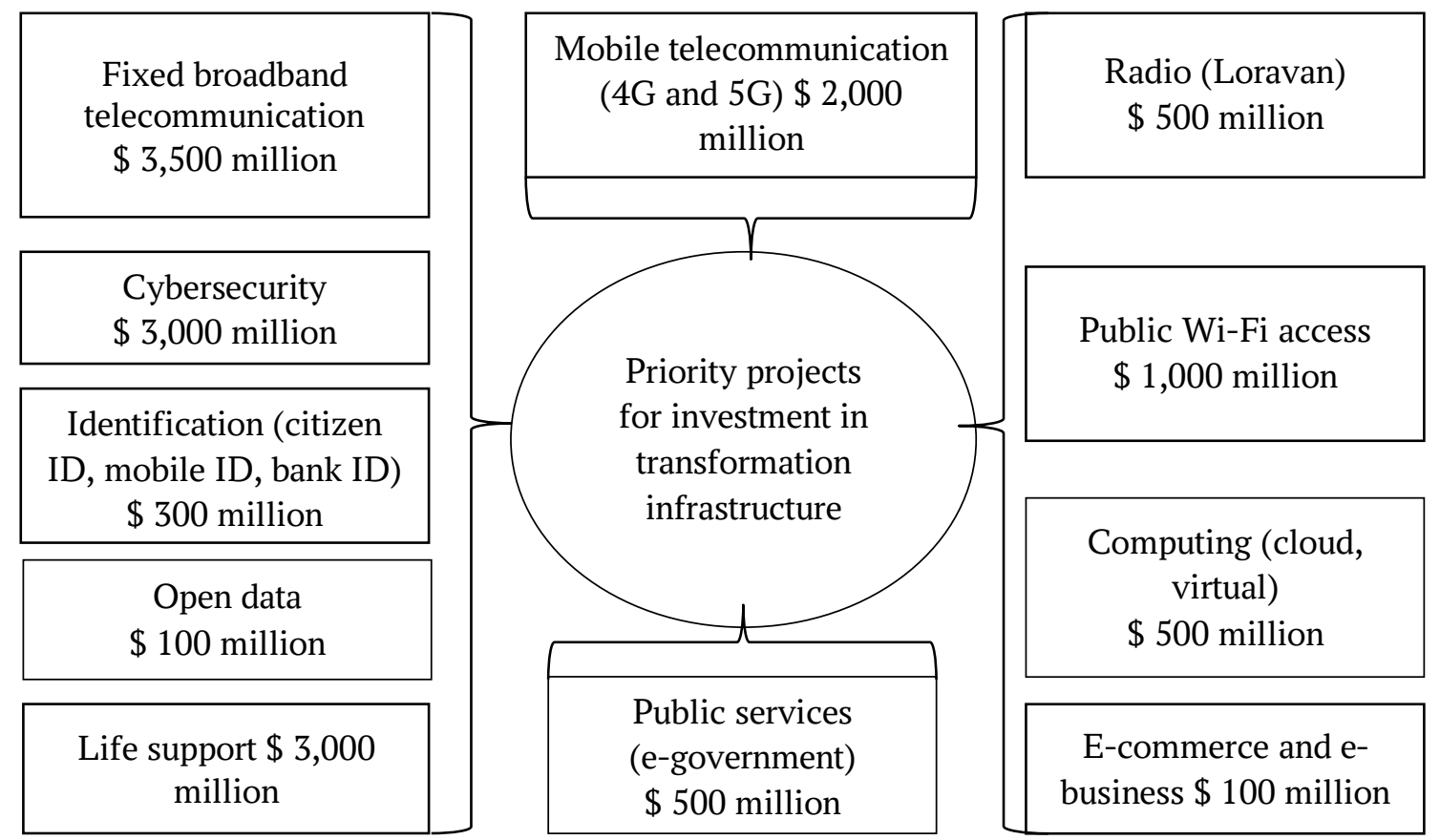

Fig. 2. Priority projects for investment in transformation infrastructure in 2020-2030

Source: grouped by author.

The Ukrainian Institute of the Future (2019) has developed the project "Ukraine 2030E - a country with a developed digital economy". The project states that "the development of the digital economy has become possible due to purposeful public policy. In the early 2020 s, the priority was the structural transformation of the Ukrainian 
economy, where innovation and digitalization became key drivers. Digitalization will be the main tool to achieve Ukraine's strategic goal to increase GDP by 8 times, up to 1 trillion dollars. The total investment in digitalization of industry, business and production by $2030 \mathrm{E}$ can reach up to 70 billion dollars, and in digital infrastructure - up to 16 billion dollars. This will increase the social and economic well-being of the population. Thus, according to the Ukrainian Institute of the Future, we forecast a promising scenario for the digital economy development.

The efficiency of investment investments in digitalization is proved. Namely, investment in the digital economy (infrastructure, digitalization of production, business, industry) will increase from $\$ 2.2$ billion in 2020 to $\$ 20$ billion in 2030. And this will accelerate additional GDP creation through digitalization to from $\$ 17$ billion to $\$ 280$ billion, respectively.

\section{Conclusions.}

It is analyzed that during the study period, GDP increased 3.3 times, while revenues from economic activities, information and telecommunications -4.2 times. The share of information and telecommunications in GDP averages $3-4 \%$ and tends to grow that is quite positive. The analysis of the capital investment dynamics by information and telecommunications section for 2010-2018 shows an increase in the share of telecommunications in its total capital investment by 0.38 percentage points. This increase was due to a slight increase in telecommunications investment in 2018 and an overall increase in capital investment. In general, over the past eight years, capital investment has increased 3.2 times, and investment by type of economic activity information and telecommunications -3.5 times.
It is proved that significant innovative changes in telecommunications, the transition to 3G and 4G in 2015 and 2018 increased the amount of investment in these periods by 14,799.9 million UAH and $11,489.7$ million $\mathrm{UAH}$, respectively. According to the growth rate, it is necessary to note the receipts in the area of computer programming and the provision of other information services, which increased 11 times (telecommunications - 3.4 times, publishing, radio, television -2.5 times).

It is noted that foreign direct investment in the economic activity of information and telecommunications has a positive trend to increase from $1,734.9$ million USD in 2010 to 2,201.1 million USD in 2018. These investments also characterize a favorable investment climate for foreign investors when investing in digitalization.

It is proved that today in Ukraine the most attention is paid to the creation of hightech and engineering clusters. In addition, the development of intersectoral alliances, R\&D centers, laboratories, incubators, accelerators, venture funds and innovation teams is promising. The strategic dominants of the economy digital transformation are determined. The main priority projects for investing in transformation infrastructure in 2020-2030 are presented.

It is substantiated that the model of financing through venture capital, business angels, grants, business incubators, accelerators, crowdfunding platforms, innovation teams is expedient for innovative projects. It can be through raising funds in the stock market, through IPOs, SPOs, ISOs, direct investment funds, mutual investment institutions, state and non-state pension funds.

\section{References}

Aleksynska, M., Bastrakova, A. and Kharchenko, N. (2018), Work on digital labour platforms in Ukraine: Issues and policy perspectives, International Labour Office, Geneva, Switzerland, 64 p.

Fishchuk, F. and Biriukov, A. (2019), “Digital economy of Ukraine: it's time to act!”, available at: https://www.slideshare.net/APPAU Ukraine/digital-agenda-ukraine (Accessed 21 September 2019).

ICT development index (2017), “Measuring the Information Society Report 2017", available at: https://www.itu.int/net4/ITU-D/idi/2017/ (Accessed 21 September 2019). 
Irtyshcheva, I., Ponomarova, M. and Dolzhykova, I. (2019), "Conceptual fundamentals of development of the food security system”, Baltic Journal of Economic Studies, vol. 5, no. 2, pp. 57-64, doi: https://doi.org/10.30525/2256-0742/2019-5-2-57-64

Irtyshcheva, I. O. and Kramarenko, I. S. (2014), "Investment attractiveness of the economy: Inter-regional asymmetries”, Regional economy, no. 2 (72), pp. 84-95.

Irtyshcheva, I., Stegney, M., Boiko, Ye., Voit, D., Hryshyna, N. (2019), “Theoretical-methodical approaches to monitoring of the level of socio-economic development of territorial units and national economy in conditions of decentralization", Perspectives - Journal on Economic Issues, no. 2, pp. 83-92, available at: http://perspectives-ism.eu/full/p192-s083.pdf (Accessed 21 September 2019).

Irtyshcheva, I., Vyshnevska. O. and Kaliuzhna, O. (2019), "Infrastructure provision of the agrarian market in the globalized environment”, Baltic Journal of Economic Studies, vol. 5, no. 5, pp. 39-46, doi: https://doi.org/10.30525/2256-0742/2019-5-5-39-46

Kramarenko, I., Senkevich, O., Andryushchenko, Ye., Prokopenko, N. and Kloyts Yu. (2019), "Features of formation of investment potential: Regional and national aspects", The Bulletin of the Kharkiv National Agricultural University of V. V. Dokuchaeva, no 3, pp. 343-356, doi: https://doi.org/10.31359/2312-3427-20193-343

Melnyk, M. I. (ed.) (2019), Inkliuzyvnyi vymir rozvytku mist - centriv dilovoii aktyvnosti Ukrainy: tendencii ta perspektyvy [Inclusive dimension of development of cities - centers of business activity of Ukraine: tendencies and prospects], Institute of Regional Studies named after M. I. Dolishnii NAS of Ukraine, Lviv, Ukraine, $55 \mathrm{p}$.

Romanenko, Ye. (2016), “The state of development of the information society in Ukraine”, Novitni informatsiinokomunikatsiini tekhnolohii $v$ modernizatsii publichnoho upravlinnia: zarubizhnyi $i$ vitchyznianyi dosvid [The latest information and communication technologies in the modernization of public administration: foreign and domestic experience], Materily IV-ho naukovo-praktychnoho seminaru [Proceedings of the IV scientific-practical seminar], Dnipro, Ukraine, March 21 - April 25, 2016, available at: http://dridu.dp.ua/konf/konf dridu/itis\%20seminar\%202016/pdf/12.pdf (Accessed 21 September 2019).

Shtepenko, K. P. and Zaburaeva, O. Yu. (2019), "Analysis of direct foreign investments in the economy of Ukraine and the precipitations of necessity of their attraction", Efektyvna ekonomika, [Online], vol. 5, available at: http://www.economy.nayka.com.ua/?op=1\&z=7040 (Accessed 21 September 2019), doi: https://doi.org/10.32702/2307-2105-2019.5.34

Simakhova, A. O. (2018), "Social prospects of the science and digital economy development in Ukraine", Social Economy, no. 56, pp. 216-221.

State Statistics Service of Ukraine (2019), “Statistical information”, available at: http://www.ukrstat.gov.ua (Accessed 21 September 2019).

Ukrainian Institute of the Future (2019), "Ukraine 2030E is a country with a developed digital economy", available at: https://strategy.uifuture.org/kraina-z-rozvinutoyu-cifrovoyu-ekonomikoyu.html (Accessed 21 September 2019).

Zagariy, V. K., Kovalchuk, T. G. and Sinilnyk, V. V. (2019), "Priority of digital economy development for Ukraine”, Priazovsky Economic Bulletin, no. 2 (13), pp. 64-68.

Zakharchenko, L. A. (2013), "State investment and innovation activity ICT companies and their development", Scientific works of ONAZ named after O. S. Popov, no. 2, pp. 105-111.

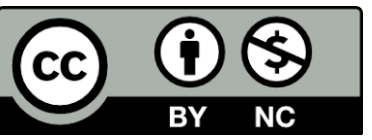

Цей твір ліцензовано на умовах Ліцензії Creative Commons «/з Зазначенням Авторства - Некомерційна 4.0 Міжнародна» (CC BY-NC 4.0).

This is an open access journal and all published articles are licensed under a Creative Commons "Attribution-NonCommercial 4.0 International" (CC BY-NC 4.0). 